\title{
Ethical dilemmas of nurses and physicians in the primary health care setting
}

\begin{abstract}
Theoretical background: Ethical dilemmas are present in everyday practice of health-care providers. The purpose of this paper is to assess ethical dilemmas of nurses and physicians working in the primary health care setting, and types of help they perceive as useful for their resolution.

Methods: 264 participants were interviewed using an anonymous questionnaire. Nurses: $\mathrm{n}=167$, women $98 \%$, average age $=42$, 1years. Physicians: $n=97$, women $=79 \%$, average age $=44,38$ years. For the purpose of this paper, a set of questions was used to identify an ethical dilemma, primary issue presented in the situation, satisfaction with the resolution of the case, and perceived usefulness of help.

Results: Main ethical dilemmas include: justice - nurses 49\%, physicians 17\%; conflict between parties - nurses $35 \%$, physicians $28 \%$; professionalism- nurses $21 \%$, physicians $37 \%$. Primary issues are: ethical - nurses 39\%, physicians $35 \%$; administrative - nurses 30\%, physicians 32\%; communicational - nurses $26 \%$, physicians $21 \%$. Average satisfaction with the resolution of the case amounts to $5(5,2)$. The types of help perceived as useful: obtaining more complete information about the patient - nurses $45 \%$, physicians $54 \%$; access to someone who knows the law, institutional policy, and/or national standards - nurses 34\%, physicians $41 \%$. Lack of help: talking through ethical issues with patients nurses $56 \%$, physicians $57 \%$; access to someone with knowledge, skills and experience in ethics - nurses 54\%, physicians 51\%.

Discussion: Ethical dilemmas are present in the everyday primary health care practice of both nurses and physicians. In this context the ethical motivation and sensitivity of healthcare professionals becomes even more important. This is why the education in nursing ethics becomes of a great importance, offering the opportunity to shift towards the 'advocacy model' of nursing. Namely, the final medical decision should be the result of a partner dialogue of all members of the healthcare team.
\end{abstract}

Volume 2 Issue 5 - 2018

\begin{abstract}
Silvana Zubović
Specialised practice of family medicine Ž. Strišković Rijeka, Croatia
\end{abstract}

\author{
Correspondence: Silvana Zubović, Specialised practice of \\ family medicine Ž. Strišković Rijeka, Croatia \\ Email silvana.zubovic.ri@gmail.com
}

Received: August 17, 2018 | Published:September 10,2018

Keywords: bioethical issues, ethics, nursing, health personnel attitudes, primary health care, questionnaire

\section{Introduction}

Today's modern medicine, in an atmosphere of post-modern scientific-technical civilization needs a new ethic. Quick and sudden social changes require rapid and urgent decisions, and then there is a real danger that threatens decisions are to be prompt, but to show that they were not very wise thoughtful. ${ }^{1}$

The results presented in this paper are the follow-up results presented at the "4 mednarodnoj scientific conferences Sole High health than Jesenice". 2

\section{Methods}

The method is an anonymous questionnaire for the survey polled 264 respondents, of which 167 nurses (98\% women, mean age 42.1 years) and 97 physicians (79\% women, mean age of 44.38 years), with the Primorsko- Gorski, Varazdin, Bjelovar, Zagreb, Karlovac, Sisak, Istria and Zadar County. The survey was conducted from January to August 2010. year, For purposes of this research used questionnaires are part of "The values of the patient's bed" (Values at the Bedside) ${ }^{3}$ with the consent of the author. The questionnaire has undergone a method of double translation (English-Croatian-English). The questionnaire consists of three parts. In the introductory part of the statement of respect for privacy, protection of confidentiality and use of heated results for research purposes only. In the second part of the questions on socio-demographic data. In the third section are questions about the ethical dilemmas that nurses and doctors face in their everyday practice in primary health care.

For purposes of this paper used the questions related to the recent description of the ethical dilemmas that the participants experienced in the workplace. Thus, participants should briefly describe the dilemma, and extract the main problem that occurred in their case. Then, using the scale "Zadovoljstva decisions" (ranging from 0 to 10 , where 0 represents the lowest and 10 highest satisfaction) selected the response. Perception scale assistance received is composed of 14 examples of forms of assistance (in the field of ethics) in order to better resolve ethical dilemmas. Respondents were asked to assess whether they have been able to get help in these ways, and are offered to them: 1 - yes 2 - I do not know, 3 - no. Using a questionnaire for the proposed study was approved by the Ethics Committee of the Health CPG. The collected data were entered into a two-dimensional relational table in the computer program Microsoft Excel (Mikrosoft, USA). Personal details of respondents are shown the frequencies and relative frequencies. As a measure of the meanyears of medical professionals used the arithmetic mean. Statistic data analysis was performed using SPSS software (version 12) and Statistica (version $8)$. 


\section{Results}

Sociodemographic characteristics of respondents are shown in Table 1.

\section{Ethical dilemma}

When asked about their recent ethical dilemma responded to 143 respondents, which is $54 \%$ of total respondents. Ethical dilemmas of both populations to match and most representing justice, conflict among the parties to the case and professionalism. The results are shown in Table 2 .

\section{The main problem}

When asked about the main problem in its own case responded to 215 respondents, representing $81 \%$ of respondents. As the main issue or problem that is occurring in their own example, and medicicinske nurses and physicians were identified: an ethical, administrative, and communication Table 3.

Table I Socio demographic characteristics of respondents

\begin{tabular}{llll}
\hline \multirow{2}{*}{ Variable } & Nurses(N=167) & Doctors(N=97) & Total(N=264) \\
\cline { 2 - 4 } Gender & $\mathbf{n}(\%)$ & $\mathbf{n}(\%)$ & $\mathbf{n}(\%)$ \\
male & & & \\
women & $163(2)$ & $20(21)$ & $24(9)$ \\
Years of work in the profession & $77(79)$ & $240(91)$ \\
5-Jan & $8(5)$ & & \\
15-Jun & $29(17)$ & $15(15)$ & $23(9)$ \\
16 and more & $130(78)$ & $19(20)$ & $48(18)$ \\
Years working in PHC & & $66(68)$ & $196(74)$ \\
5-Jan & $22(13)$ & & $47(18)$ \\
15-Jun & $50(30)$ & $25(26)$ & $67(25)$ \\
16 and more & $95(57)$ & $17(18)$ & $153(58)$ \\
Professional development & & $58(60)$ & $3(1)$ \\
I. first daily & $16(10)$ & & $41(16)$ \\
2. second per week & $51(31)$ & $25(26)$ & $96(36)$ \\
3. third monthly & $75(45)$ & $45(46)$ & $99(38)$ \\
4. per year & $18(11)$ & $24(25)$ & $21(8)$ \\
5. never & $3(2)$ & $3(3)$ & \\
\hline
\end{tabular}

The sum of relative frequencies is not always 100 because not all respondents answered all questions

Table 2 An example of the ethical dilemmas of PHC workers

\begin{tabular}{|c|c|c|c|c|}
\hline & \multirow{2}{*}{ Dilemma } & \multirow{2}{*}{$\begin{array}{l}\text { Sisters(N=89) } \\
n(\%)\end{array}$} & \multirow{2}{*}{$\begin{array}{l}\text { Doctrors }(\mathrm{N}=54) \\
\mathrm{n}(\%)\end{array}$} & \multirow{2}{*}{$\begin{array}{l}\text { Total( } N=\mid 43) \\
n(\%)\end{array}$} \\
\hline & & & & \\
\hline I & Decisions about end of life & $6(7)$ & $2(4)$ & $8(6)$ \\
\hline 2 & The autonomy of the patient & $5(6)$ & $3(6)$ & $8(6)$ \\
\hline 3 & Justice & 44(49) & $9(17)$ & $53(37)$ \\
\hline 4 & The conflict between the parties in the case of & $31(35)$ & I5(28) & $46(32)$ \\
\hline 5 & Professionalism & $19(21)$ & $20(37)$ & $39(27)$ \\
\hline 6 & Speaking Truth & $9(10)$ & l & $9(6)$ \\
\hline 7 & Religious or cultural reasons & $5(6)$ & l & $5(3)$ \\
\hline 8 & Other & l & l & l \\
\hline
\end{tabular}


Table 3 The main ethical issue or problem in their own case

\begin{tabular}{|c|c|c|c|c|}
\hline & \multirow{2}{*}{ Problem } & \multirow{2}{*}{$\begin{array}{l}\text { Sisters }(N=140) \\
n(\%)\end{array}$} & \multirow{2}{*}{$\begin{array}{l}\text { Doctors(N=75) } \\
n(\%)\end{array}$} & \multirow{2}{*}{$\begin{array}{l}\text { Total( } N=2 \text { I 5) } \\
n(\%)\end{array}$} \\
\hline & & & & \\
\hline 1 & Professional & $6(4)$ & $3(4)$ & $10(5)$ \\
\hline 2 & Communication & $36(26)$ & $16(21)$ & $52(24)$ \\
\hline 3 & Ethics & $55(39)$ & $26(35)$ & $84(39)$ \\
\hline 4 & Administration & $42(30)$ & $24(32)$ & 63(29) \\
\hline 5 & Other & I (I) & $6(8)$ & $6(3)$ \\
\hline
\end{tabular}

\section{Satisfaction with decisions taken}

When asked about satisfaction with decisions made in our own recent example of ethical dilemmas through the scale of 1-10, stated that $74 \%$ of nurses with an average satisfaction of 4.77 , and $65 \%$ of physicians with an average value of 5.76. The total average satisfaction is 5(5.2). There is a difference in the declaration of satisfaction, because they are nurses, $12 \%$ expressed complete dissatisfaction with the decisions made in our own case, and doctors at $5 \%$. The distribution of respondents is shown in Figures $1 \& 2$.

\section{Perception of help received}

As for the perception of support provided to better solve their ethical dilemmas, the question was answered by 200 respondents, representing $76 \%$ of respondents. The nurses and doctors emphasize obtaining complete information about the patient's condition and contacting the person who knows the laws, protocols, institutions and/ or national standards. The sisters are listed recruitment literature in ethics relevant to the case and clarify the ethical dilemma of physicians. Both populations indicate that they at least were able to get help to talk of ethical dilemmas with the patient and the contact person with special knowledge, skills and experience in ethics. Medical and sisters are not sufficiently emphasize the study of modern ethical standards, and resolving conflicts between different views, and suggestions for additional physicians ethically most appropriate course of treatment. The results are shown in Table 4.

Table 4 Perception of help received

\begin{tabular}{|c|c|c|c|c|c|c|}
\hline \multirow{2}{*}{$\begin{array}{l}\text { Variables that } \\
\text { Perception of help received: }\end{array}$} & \multicolumn{2}{|l|}{$\begin{array}{l}\text { Yes } \\
\mathrm{n}(\%)\end{array}$} & \multicolumn{2}{|c|}{$\begin{array}{l}\text { Do not know } \\
\text { n(\%) }\end{array}$} & \multicolumn{2}{|l|}{$\begin{array}{l}\text { No } \\
\text { n(\%) }\end{array}$} \\
\hline & $\begin{array}{l}\text { Nurses } \\
(\mathrm{N}=130)\end{array}$ & $\begin{array}{l}\text { Doctors } \\
(\mathrm{N}=70)\end{array}$ & $\begin{array}{l}\text { Nurses } \\
(\mathrm{N}=130)\end{array}$ & $\begin{array}{l}\text { Doctors } \\
(\mathrm{N}=70)\end{array}$ & $\begin{array}{l}\text { Nurses } \\
(\mathrm{N}=130)\end{array}$ & $\begin{array}{l}\text { Doctors } \\
(\mathrm{N}=70)\end{array}$ \\
\hline I. First clarifying ethical dilemmas & $30(23)$ & 25(36) & $36(28)$ & $13(19)$ & $64(49)$ & $32(46)$ \\
\hline 2. Discussion of ethical dilemmas with patient & $30(23)$ & $17(24)$ & $26(20)$ & $12(17)$ & 73(56) & 40(57) \\
\hline 3 obtain complete information about patient's condition & $58(45)$ & 38(54) & $29(22)$ & $10(14)$ & $43(33)$ & $20(29)$ \\
\hline $\begin{array}{l}\text { 4. Contacting people with special knowledge, skills and } \\
\text { experience in ethics }\end{array}$ & $36(28)$ & $21(30)$ & $23(18)$ & $\mathrm{II}(16)$ & 70(54) & $36(51)$ \\
\hline $\begin{array}{l}\text { 5. contact person who can provide expert advice for } \\
\text { ethical most appropriate course of treatment }\end{array}$ & $36(28)$ & 20(29) & $28(22)$ & $15(2 \mid)$ & $66(51)$ & $33(47)$ \\
\hline 6. resolving conflicts between different positions & $21(16)$ & $16(23)$ & $36(28)$ & $18(26)$ & 72(55) & $35(50)$ \\
\hline $\begin{array}{l}\text { 7.A additional suggestions for ethical most appropriate } \\
\text { course of treatment }\end{array}$ & $26(20)$ & $16(23)$ & $34(26)$ & $16(23)$ & $66(51)$ & $36(51)$ \\
\hline $\begin{array}{l}\text { 8. contact person who knows laws, protocols, institutions } \\
\text { and / or national standards of }\end{array}$ & $44(34)$ & 29(4I) & $24(18)$ & $16(23)$ & $60(46)$ & $24(34)$ \\
\hline 9. recruitment literature in ethics relevant to the case of & $63(48)$ & $24(34)$ & $24(18)$ & $18(26)$ & $42(32)$ & $26(37)$ \\
\hline $\begin{array}{l}\text { 10. professional support concerning(Ethical) correctness } \\
\text { of the decision }\end{array}$ & $31(24)$ & $21(30)$ & $32(25)$ & $14(20)$ & $66(51)$ & $33(47)$ \\
\hline II. study of contemporary ethical Standard & $24(18)$ & $14(20)$ & $32(25)$ & $23(33)$ & 73(56) & $29(41)$ \\
\hline 12. "Weighing" of possible outcomes of the situation & $24(18)$ & $17(24)$ & $43(33)$ & 20(29) & $60(46)$ & $31(44)$ \\
\hline 13. feeling more comfortable in his own role & $34(26)$ & 20(29) & $42(32)$ & $16(23)$ & $52(40)$ & $32(46)$ \\
\hline $\begin{array}{l}\text { 14. preventing the occurrence of new(Ethical) problems } \\
\text { and the difficulty of }\end{array}$ & $36(28)$ & 20(29) & $34(26)$ & $15(2 \mathrm{I})$ & $55(42)$ & $32(46)$ \\
\hline
\end{tabular}




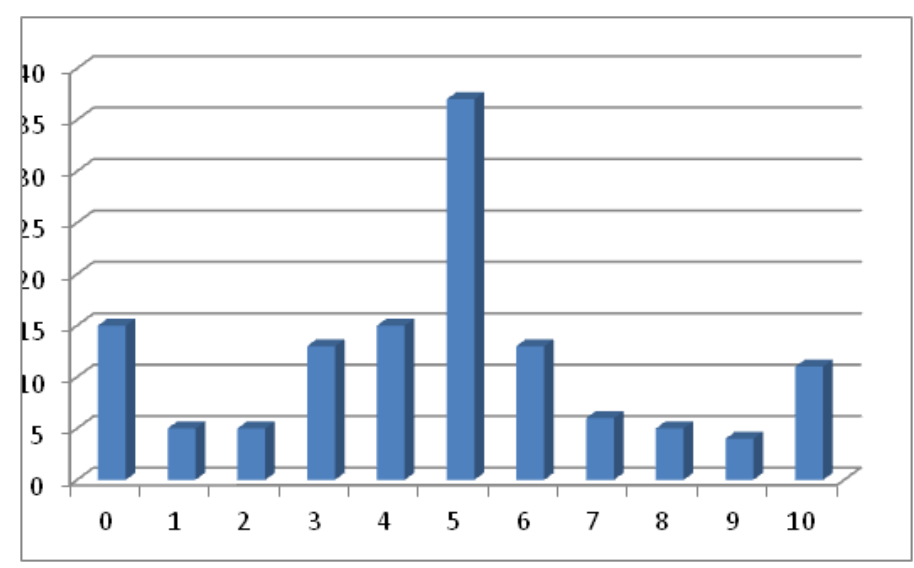

Figure I Satisfaction with decisions made by nurses.

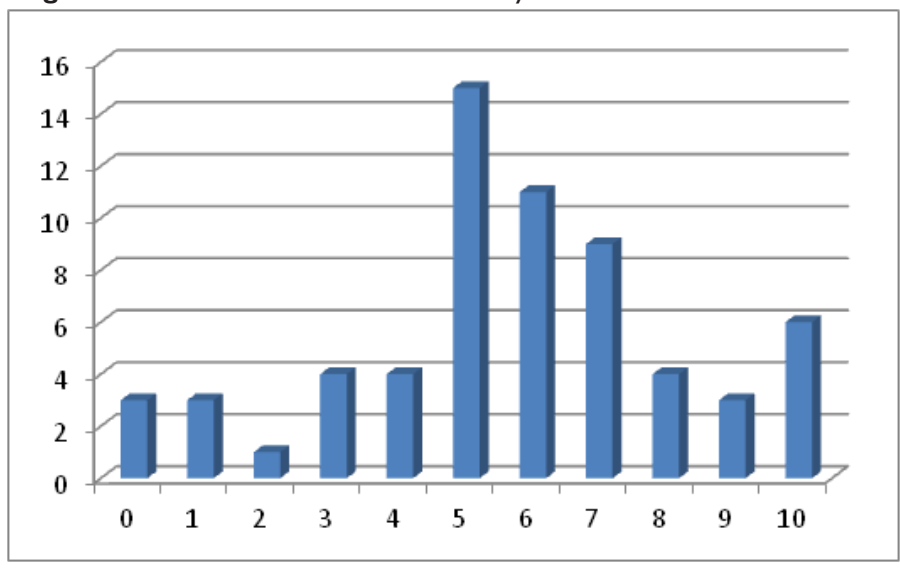

Figure 2 Satisfaction with decisions taken at the doctor.

\section{Discussion}

The coincidence in the results between populations can be explained as a consequence of socio-demographic picture, because the PHC and between nurses and physicians dominate among women, with a total work in the profession 16years or more. It might be concluded that the so-called.

"Women's ethic" is characterized by reference to the conscience and empathy accustoming ourselves to the role, with emphasis on care, welfare and harmony in the relationship, ${ }^{4,5,6}$ as well as long-standing practice influenced the experiential experience, therefore, thinking, attitudes, perception of a problem (dilemma) are similar. ${ }^{7}$

\section{Ethical dilemma}

Like most of their own ethical dilemmas, and nurses and doctors say justice, conflict among the parties to the case, and professionalism. The principle of fairness is closely related to the nursing profession that requires as a basic goal of patient care. The nurse must be emotionally mature and stable in order to understand and cope with health problems and ethical dilemmas. The nurse must be a caring, willing to accept responsibility, work independently and in teams, conscientiously and critically implement what is required and must recognize when to consult with others. ${ }^{8}$ The nurse in PHC is part of the interdisciplinary team as they share their competencies.

Problems concerning the relationships with patients are common because of the large interaction between the physician-patient and nurse-patient, and the great need for the professionalisation of relationships in modern medicine, not only evolve in the direction of increasing patient autonomy in relation to the doctor (Informed Consent ), but in the direction of less dependence nurses of the doctor. ${ }^{9}$ The system includes primary health care treatment and outpatient care of patients, so that workers in primary health care "gatekeeper", often first on the impact of selection and differentiation of medical treatment due to inappropriate patient requests for procedures and treatments, In appropririate Requests for Treatments and Tests. ${ }^{10}$ The nurse has a right to respond in situations where noted malpractice of other members of the health team. One of the important tasks in the ethical sense to stick to the principles of professional responsibility to minimize the damage and the rational use of medical procedures. ${ }^{11}$

\section{The main problem is the perception of help received}

As the main problem that appeared in their own example and nurses, and medical doctors have rendered ethical, administrative, and then communication. These results significantly related to the results obtained on the perception of support, with both populations indicate that they at least were able to get help to discuss ethical dilemmas with the patient, and contact person with special knowledge, skills and experience in ethics. Nurses also emphasized the insufficient study of contemporary ethical standards, although it emphasized that the most professional training per week, or month. Professional ethics, and nursing and physician, prescribes detailed basic principles to be followed in carrying out its mission, duty to the patient, to other nurses/doctors and nursing/medical chamber. Nurse for every patient must take care unlimited, selfless and immense, so apart from the professional knowledge and skills, must be human persons worthy of confidence. ${ }^{12}$ New achievements in science and technology set new ethical and moral issues that challenge the implemetaciji passed the law in everyday practice in working with patients and can be divided into three groups: ethical issues at the beginning of life, in the prime of life, and at the end of life. ${ }^{13}$ The administrative problem has become accentuated in recentyears due to changes in the health system and the inevitable computerization, which still represents a problem rather than a convenience. In addition, no more services for the planning and analysis at community health centers, which monitored and analyzed the performance of health care and the necessary planning and operation activities for the next fiscal year (Car, 2011).

i. The powers of nurses in PHC clinics are very small and mostly oriented administrative procedures: Checks to ensure patient

ii. Checking the origin of the patient general practice/family medicine,

iii. Issuing and billing the insurance company, signed by a physician,

iv. The implementation of medical procedures prescribed by doctors, such as vaccination, treatment of wounds, etc. ${ }^{14}$

Nurses are faced with an ethical component communication (compassion).${ }^{15}$ Good communication skills, patience and sensitivity to human problems that are an integral part of all nursing procedures are necessary to create a relationship of trust. ${ }^{8}$ Despite the fact that many doctors still consider nurses mere servants, they have a fundamental role in mediating between doctors and patients. In any case, for the protection and welfare of the greatest accomplishments of patients, a necessary teamwork and integration of health professions for the success of various therapeutic effects. ${ }^{7}$ When nurses identified 
inadequate study of contemporary ethical standards due to the transformation of values and responsibilities demanded of us by the European Union. It should be noted discrimination in educational opportunities that would be reached the minimum standard of education required by the EU. Specifically, to work in primary health care clinics do not require a highly educated nurse, but so. "Middle nurse". ${ }^{7}$ However, modern nursing has made the shift from a military model and closer to the model law (engl. advocacy model) sorority nurse who is a patient's/client's representative. It contains three approaches: legal-protection model (nurse patient's rights defender); protective value (nurse protects the patient from the standpoint of the moral standards of their profession); The respective model (nurse protects the patient's individuality, dignity, privacy), but requires changes in traditional inferior position of the sisters, for assumption of this model is the professional autonomy of nurses. Nurses need not only appropriate but also the ethical education of a higher level of individual morality (Segota, 1997).

\section{Satisfaction with decisions taken}

Average satisfaction with the decisions made during their recent resolution of ethical dilemmas among populations does not differ significantly. However, significant differences in the declaration of satisfaction, which is a lot more nurses than doctors dissatisfied with the decisions. The role of nurses in making ethical decisions regarding patient is still not entirely clear. The health institutions are mainly investigates the role of physicians in making important decisions for the patient and minimal or no attention to the decisions adopted by the nurse. However, in practice comes into play and their ability, both in recognition and appreciation of moral values and in making concrete ethical decisions, which proved that it is not at all simple and easy. No one may or may challenge the independence of the profession during the process of making important health decisions. The sisterhood "can not be reduced to the 'aesthetic' and 'executive' component of the health team, because nursing has its irreplaceable 'therapeutic role' of an effective single entity within the therapeutic doctor-patient relationship". ${ }^{16}$

\section{Conclusion}

Nurses and doctors would need to accept the fact that the success of their action is not hiding in quantity but in quality of performed activities, the authority of the arguments rather than the position of authority, the conduct of business events and processes of governance rather than people, trust and willingness of the transfer of certain responsibilities to your co-workers, and not only a consequence of the transfer of their own bad decisions and assessments. ${ }^{17,18,19}$ Nursing ethics is not a reflection of the fashionable one's desires and wishes. Nursing ethics is simply a pressing need an honorable medical profession that from day to day coping with the increasingly difficult conditions and circumstances technologized, sophisticated and totally poznanstvenjene medical practice. ${ }^{20}$

\section{Acknowledgements}

None.

\section{Conflict of interest}

Author declares that there is no conflict of interest.

\section{References}

1. Matulić T. Metamorfoza kulture: teološko prepoznavanje znakova vremena u ozračju znanstveno-tehničke civilizacije. Zagreb: Glas Koncila; 2009;49(1):119-126.

2. Vozila S, Sorta-Bilajac I. 4. mednarodna znanstvena konferenca Visoke šole za zdravstveno nego Jesenice: Na dokazih podprta zdravstvena obravnava - priložnosti za povezovanje zdravstvenih strok, potreb pacijentov in znanj. Zbornik predavanj $z$ recenzijo. Ljubljana: Visoka šla za zdravstveno nego Jesenice; 2011:9-10.

3. Hurst SA, Perrier A, Pegoraro R, et al. Ethical Difficulties in Clinical Practice: Experiences of European Doctors. J Med Ethics. 2007;33(1):51-57.

4. Ford MR, Lowery CR. Gender differences in moral reasoning: a comparison of the use of justice and care orientations. J Pers Soc Psychol. 1986;50(4):777-783.

5. Gibbs JC, Kevin DA, Burkhart JE. Sex differences in the expression of moral judgment. Child Development. 1984;55(3):1040-1043.

6. Brabeck M. Moral judgment: theory and research on differences between males and females. Development Review. 1983;3(3):274-291.

7. Vozila S. Etičke dileme zdravstvenih djelatnika u primarnoj zdravstvenoj zaštiti: diplomsko delo. Rijeka: Sveučilište u Rijeci, Medicinski fakultet; 2011.

8. US Preventive Services. Task Force: Guide to Clinical Preventive Services. 2nd ed. Baltimore: Williams \& Wilkins; 1996.

9. Šegota I. Etika sestrinstva. Zagreb: Pergamena; 2014.

10. Brett AS, Mc Cullough LB. When patients request specific interventions: defining the limits of the physicians obligation. $N$ Engl $\mathrm{J} \mathrm{Med}$. 1986;315:1347-1351.

11. Truog RD, Brett AS, Frader J. The problem with futilyti. $N$ Engl J Med. 1992;326(23):1560-1564.

12. Etički kodeks medicinskih sestara. Dostopno na; 2012.

13. Čehok I, Koprek I. Etika, priručnik jedne discipline. Zagreb: Školska knjiga; 1996.

14. Medicinske sestre u ordinacijama primarne zaštite. U: Informacijski sustav primarne zdravstvene zaštite Republike Hrvatske. 2012.

15. Fučkar G. Proces zdravstvene njege. Zagreb: Medicinski fakultet Sveučilišt u Zagrebu; 1992.

16. Jonsen AR. The Birth of Bioethics. Hastings Center Report. 1993;23(6):S1-S4.

17. Klose A. Poduzetnička etika. Zagreb: Školska knjiga; 1997.

18. Baloban S. Etika i poduzetničko gospodarstvo. Bogoslovska smotra. 1992;62(1-2):78-92.

19. Blanchard K, Peale NV. Moć etičkog poslovanja. Zagreb: Horvat elektronika; 1990.

20. Matulić T. Identitet, profesija i etika sestrinstva. Bogoslovska smotra. 2007;77(3):727-744. 